\title{
Legal Frame for the Children Rights under Refugees Situation, as in Albanian Case
}

\author{
Ph.D (c) Lisjana Çukaj
}

University European of Tirana; Email:liselda2009@yahoo.com

\section{Doi:10.5901/ajis.2015.v4n3s1p648}

\begin{abstract}
During the last years became evident a tendency of increasing the number of refugee children,considering their age and maturity, they need special care under the refugee situation. The position of refugee children in the convention is very clear, it obligates the countries to insure the necessary measurements needed to the refugee children, to enjoy the basic rights of the convention as well as the rights of other international instruments. Although this phenomena is a relatively new case for Albanian society, including special categories such as children. Albania is charged to guarantee children rights observance and application under the refugee situation in conformity to the convention.Description of the rights in Albanian context is performed in order to identify the legal deficiency. Via analyses is aimed the Albanian legislation improvement from the responsible institutions, in order to protect the children's right under the refugee situation. The effective defense will be possible only if the state will insure certified rights under children's rights convention and government will assist in sharing encumbrance for options ratification in refugee's children assimilation. In the last years the legislation improvement in relation to the human rights and children's rights can not be denied.However it can not be denied the fact that most of laws remained just declarative and inapplicable, and did not had the right impact.New legal initiatives should be undertaken.
\end{abstract}

Keywords: The Convention of Children Rights , National law, Administrative and Judicial practices.

\section{Introduction}

Refugee children face very dangerous risks as much as it relates to their defense and welfare in comparison to common children. The Convention of Children Rights (CRC) is the most ratified treaty all over the world.It constitute the nucleolus of the international law for children rights, and is especially important for refugee children as it determines full standards for them. With the system change Albanian was approaching to reach and apply standards in many fields, including even the ones offering refugees protection conform to international standards. The convention of children rights was ratified even from Albania it has a special importance whose dispositions are find embodied in the most important national acts such as constitution, codes, laws,etc.Via analyses of various levels used in a plan compared to the international standards, with the ones set by the international convention for children's rights and their execution in national level, is aimed the comparison of each relevant legal act with the convention standard. This by referring to the appropriate articles of the standard part which finds lawful regulation by noticing either correspondence or failure. Is charge of the Albanian state that via analyzing and frequent review of the legislation, to make possible the fulfill of lawful deficiency.The effective defense of refugee children will be possible only if the state will suggest the rights and the guaranteed defense under the convention of Children Rights The initiative of Albanian govern especially in the frame of integrative processes to the UE,the rigorous application of legislation in relation to the refugee, including special categories such as children.

\section{Incorporation of Convention for Children Rights in the Domestic Right}

Convention is the basis for the rights of refugee children in the international law, fulfilled with two of its protocols. It is a comprehensive treaty which contain dispositions for many aspects of children life.The general principles described are such as: a) non discrimination, b) the highest interest of the child c) survival and development, d) and participation principle. The position of refugee children in the convention is very clear, it obligates the countries to ensure the necessary measures, to be engaged with the refugee children to enjoy the four basic rights of the convention, as well as the right of other international instruments in which they are part. This convention is important because determines full standards for refugee children (CRC,1989). After the system change in Albania, this was the first international act that Albania ratified on 27 February 1992. It became part of the domestic legislation and had supremacy on the laws of the country (Constitution of the Republic of Albania,1998).

Although it was not applied immediately in practice due to the conditions in which Albanian was, as a country which 
just came out from totalitarian regime, even in this period there was no law for asylum.Later in the constitution of the year 1998 is guarantee the right of foreigners to get sheltered in the Republic of Albania without determining to whom it refers,so not referring especially to children.Constitution through its dispositions guarantees the right of shelter without determining neither procedures,nor the levels of application of this right without referring especially to children.

\section{Adhering to the Principle of Non-discrimination in National Law}

The general principles of non- discriminig in the convention are the various treatments of stooping which are arbitrar and objectively unjustified. Although there is not a clear definition of the word discrimination, differential treatment in similar cases without objectively justifiable reasons,constitute, discrimination (WoutlerVandenhole, 2005). After the approval for the first time of the law on asylum in Albania,children have been involved in refugee general term.without stating any direct definition of refugee children excluding a reference for children where is provided "Asylum granting based on the principle of family settlement"and stated that the one who benefits from the right of asylum are the spouse and children under the age of eighteen (Law"For Asylum in the Republic of Albania",1998). So it is set a condition to benefit asylum on family settlement being dependent child of a parent, and children who are dependents of a guardian or married are unable to benefit the status because of family reunion.

Nothingless in the same conditions and elements that form the basis for the determination of refugee status may result in providing different levels of protection of minors of the same family. This exception of being dependent child is not found at the Convention of Children Rights, or child being married under eighteen are not provided as exempted conditions from (CRC). Another discrimination case in the national aspect is minors entry where is provided that for persons under sixteen years old can apply for a visa, permit or seek to enter Albania with the permission of legal guardians or accompanied by adults.From this rule are excluded those who enter as asylum seekers,and in this case is a clear differentiation between the minor just as alien and minors as asylum seekers which is outside the scope of regulation of this law (Law for the Foreigners,2008). Even are not provided even procedures for joining the minor with the family of origin which would correspond to the principles of the Convention of Children Rights (CRC). Neither here is not respect the principle of non-discrimination obligation flowing from Convention of Children Rights .

\section{The Best Interest of the Child}

The best interest of the child is the first thing in which is focused the convention of the children rights. In article 3 (1) of the Convention on children's rights is embodied what is known as the best interest of the child. In all actions focus on children whether undertaken by public or private social welfare institutions,courts, administrative authorities with the highest interest of the child shall be a primary consideration (Kristi Kurki -Suonio,2000). At national level, this principle is often not respected as such in the following cases.During the interviewing procedure of the minor refugees in Albania is not mentioned the best interest of the child as a guiding principle. So he may be associated by the advocate, although the procedure guarantees participation and hearing the opinion of minor is not mentioned the best interest of the child as a guiding principle. Also there no adjustments provided regarding the definition of the role of guardian of the minor asylum seekers. Given that one of its legal functions is representation,considered in relation to the obligation of asylum seekers to cooperate, for clarification the facts, to provide information, to perform the official orders for presentation and reporting in front of the Authorities. To submit documents in possession, all these tasks are very unsuitable to be met by a minor asylum seeker. There is not mentioned even in cases where the minor who benefits asylum with the parents as well as when it is not benefiting economic aid from refugee's centres. In cases of unaccompanied children who have been granted asylum in Albania is possible their accommodation in social care centres applying equally to Albanian citizens, refugee offices provides all the necessary documentation at the central commission of State Social Service, when required placement in public residential centres. On the other hand the refugee offices may contact non-public residential centres licensed which offer various services (Law"For Asylum in the Republic of Albania",2009). In both these cases there is found no reference for the minor and as a consequence procedures for them should be such mentioning at least the best interest if the child,choosing the best alternative of guardian in cases of unaccompanied children, as guardian families, registration in institutions as the last option etc. 


\section{Survival and Development}

Article 6 of (CRC) provides that every child has the has the inherent right of life and this right should be protected by law.Article 6(2) fulfils the recognition of this right as an obligation of the state to ensure the maximum extent necessary protection and child development(CRC,1989). The right of life and survival are essential prerequisites to enjoy the many rights protected by the Convention of Children Rights. The right and survival protection serves to the reinforcement of rights embodied in the Convention.Realization of such rights as health,the right of education etc. Therefore temporary protection on humanitarian grounds, according to the Albanian law provides for the granting of temporary protection status to a person based on forecasts of international instruments ratified by the Republic of Albania. Explicitly stated in article five as one of them (Law"For Asylum in the Republic of Albania",2009). This prediction is very important and in conformity with Article 22 (1) of the (CRC) where protection for humanitarian reasons is one of the situations where minors must be guaranteed protection. This forecast goes further in accordance with Article 2 of the (CRC) to the minors is guaranteed protection for as long as is under the jurisdiction of Convention States parties (CRC,1989). So people who were given temporary protection for humanitarian reasons are guaranteed the right of non-refoulement,without which all other rights guaranteed because of status and would be unenforceable,that right applies fully in national law

\section{Legal Gaps for the Realization of Children's Rights under the Refugees Situation}

Although we have a law on asylum, were found several deficiencies in the implementation in practice. So on the arrival of refugee children in Albania at the police authorities, they receive a written request of the asylum seekers who notify the competent authorities, and are kept for 10 hours at the police to escort them in the refugees' centre. This procedure is not accelerated for minors who because of age may not be able to write or to formulate a request for asylum. As well as keeping them in the police environments is an inadequate measure (Decision of the Council of Ministers on entry,stay and treatment of foreigners in the Republic of Albania,2000). Then is the National Commissioner for Refugees, which has the duty to ensure every unaccompanied asylum seeker under eighteen a guardian, appointed in accordance with Albanian law, to represent and protect the interests of asylum seekers. This right comes more as an obligation for national commissioner for refugees than as a refugee child's right. There is no article which determine the rights of asylum seekers (Law" For Asylum in the Republic of Albania",2009). Unaccompanied minors granted asylum has the right of family settlement with brothers and sisters,stepfather stepmother and other family members to live together legally or who are minors, the unmarried. As a condition for family settlement with minors except parents, brothers and sisters, who must be unmarried minor. The right for family settlement is recognized to the minor even with the guardian or with any another relative,not in a direct line from the country of origin which is consistent with Article 22 and Articles 5 , 9,10 of the(CRC). Here is emphasized the principle of best interests of the child which must be considered in the European convention for the rights of children during the review of the application of a minor at the refugee office.

This provision here is not in the right place because it is located where it is spoken for family settlements procedures, as the person has been granted asylum while reference provision is made to the application reviewing procedure. As long as a right does is not contrary to the restrictions defined by law the alien who has been granted asylum is treated equally with the Albanian citizen.It is recognized the right of education to the citizens who have obtained asylum just like the Albanian citizens.Albanian language teaching is considered as an obligation of the office for refugees by organizing courses for Albanian language, not as a right for the minor (Law,"For Integration and family settlement of persons who had granted asylum in the Republic of Albania",2003).Although these articles tend to detail the rights in relation to the observance of the right of education no reference for minors is found as subject and the fact that he is assisted in these proceedings by the representative or guardian or a representative office for refugees in conditions when the alien is unaccompanied minor.

\section{Improvement of Albanian Legislation}

Finally, the new law for asylum in the Republic of Albania determination of minors is performed through the special provision Article 3 point (e) the minor "unaccompanied" is the stateless person under eighteen unaccompanied by an adult responsible for him, or was left unaccompanied at the time of entry into the territory of the Albanian Republic, and as long as he is not effectively under his care (Law"For asylum in the Republic of Albania,2014). To the Minors must be appointed a guardian, such a right is also effective for the unaccompanied minors in temporary or complementary protection. The procedure for determining the guardian is attended with priority and assisted by the responsible authority 
for asylum and refugees. Also the application for asylum of minor is treated promptly so are omitted the waiting hours provided by the previous law, for as much as possible children of a family should be kept together.Also the best interest of the child shall be a the primary consideration.It is provided to equip the minor with travel document, such a request for this document is presented by one of the parents, by the guardian or by the representative of attorney. The minor is provided with identity cards, travel document valid for five years. Refugee over sixteen years old is provided with identity cards, travel document valid for ten years. The procedure for their provision is defined by the directive of the responsible minister.Asylum seekers have the right of accommodation together with their parents or adult family members or responsible for them.

Minor asylum seekers profit full health services as for minor Albanian citizens. During the examination of the application procedure for asylum the unaccompanied asylum seekers minor is heard and interrogated in the presence of a psychologist or adult who is familiar with his character or enjoys his confidence. The application review for family settlement with the new law is provided in case when the application for family settlement is related to an unaccompanied minor the decision is taken within twenty days from the date of submission for the application, during the review of this application the decision-making body should take in consideration the best interests of the child. So the unaccompanied minor refugee has the right to apply for family settlement with parents, sisters, brothers, other family member who cohabiting legally or who are minor and unmarried. When these people in close relation in straight lines can not be found the unaccompanied minor has the right to request family settlement with the legal guardian or with another relative, not in straight lines.In terms of temporary protection the minor has the right for family settlement has not yet created his own family and spouse of the alien who has been granted temporary protection.

\section{Administrative and Judicial Practice}

Based on the law for asylum in the Republic of Albania the refugees office is the administrative body who examines the asylum petitition. The decrees of this office may be appealed in administrative ways at the National Refugee Committee.After this administrative review in two levels the decisions taken are judicially appealable. In the actual prtactice all applications for asylum were made by adults. There have been no cases of application for asylum by minors which means there were no cases of unaccompanied children. In cases when together with adults were also minors from refugees offices was applied Article 6 of the Law on Asylum granting of asylum on the grounds of family settlement,which means they benefit asylum through their parents (Law"For asylum in the Republic of Albania",2009). Status who also preserve in the case of death, divorce or dissolution of marriage that parent who had received asylum. They hold this status that even in the case of death, divorce or marriage dissolution of the parent who had been granted asylum. Judicial practice in the decisions given up to now by the judiciary has not been any case where the minor was presented as asylum seekers. Applicants for asylum are considered and have received refugee status or humanitarian protection person on the basis of Articles 4 and 5 of the law on asylum in the Republic of Albania.

\section{Conclusions}

Albania has made progressive steps towards the ratification of a number of international acts in order to protect human rights, including providing protection to refugees in accordance with international standards. Improvement of legislation in recent years for the protection of human rights including children's rights can not be denied. The position of children refugee in the convention is very clear, he obliges states to provide the necessary measures for refugee children to enjoy the basic rights of the convention as well as the rights of other international instruments in which it is party. Description of rights in the Albanian context is done in order to identify the legal gaps initially observed that many of the rights arising as liabilities, through an analysis of the Albanian legislation aims to improve the responsible institutions, in order to protect the rights of children under the situation of refugees.Effective protection of refugee children will be possible only if the state will provide the rights and protection guaranteed under the Convention on the Rights of the Child. It is the duty of the Albanian government to review time to time the legislation, to enable the completion of legal gaps.

\section{References}

Kristi Kurki -Suonio 2000,Joint Custody as an interpretation of the Best Interests of Child in Critical and Comparative Perspective,"International Journal of Law,Policy and Family. The best interes of child is the most important principle in child law " Oxfrod Journal,p.14,183

Woulter Vandenhole 2005,Non-Discrimination and Equalityin the View of the UN human Rights Treaty bodies Antwerpen, Intersentia, 
p.79.

Publication Centre,2009"Constitution of the Republic of Albania", Tirane, articles,5,40.

The Convention of children rights,UN,1989; (Signed and dated 01/26/1990 ratified by date27/02/1992), articles.1,2.

Decision of the Council of Ministers on entry,stay and treatment of foreigners in the Republic of Albania,date 4.08.2000, $\mathrm{Nr} 439$.

Law no.8432, date14.12.1998 "For Asylum in the Republic of Albania",changed by law no.10060,date 26.01.2009 "For some additions and changes in the law no. 8432,date 14.12.1998," For asylum in the Republic of Albania, articles.4-7,18,24,26.

Law,17.07.2008."For the Foreigners".Official Journal,17.07.2008, no. 995, article.6

Law,03.07.2003" For Integration and family settlement of persons who had grantes asylum in the Republic of Albania".Official Journal,03.07.2003,no 9098,article.7.

Law18.09.2014"For asylum in the Republic of Albania".Official Journal,18.09.2014, no.121,articles.3-27,33,64,73. 